\title{
THE NATURE OF EDUCATIONAL PLANNING FOR SUSTAINABLE DEVELOPMENT OF THE SCHOOL SYSTEM IN SOUTH-SOUTH OF NIGERIA
}

\author{
Scott Ekere ${ }^{1}$ \\ ${ }^{1}$ Affiliation not available
}

September 29, 2021

THE NATURE OF EDUCATIONAL PLANNING FOR SUSTAINABLE DEVELOPMENT OF THE SCHOOL SYSTEM IN SOUTH-SOUTH OF NIGERIA

BY

DR. (MRS.) SCHOLASTICA C. O. EKERE

Department of Educational Administration and Planning

University of Calabar-Calabar

Scottekere@gmail.com

Tel: 08034509445

DR. EBUARA, V. O.

Department of Educational Administration and Planning

University of Calabar - Calabar

ebuarav@yahoo.com

07030731334

Abstract

The purpose of this study was to examine the nature of planning education for sustainable development of schools in the South-South of Nigeria. The design of the study was ex-post facto design. The population of the study consisted of all education stakeholders in selected states of South-South of Nigeria. The instrument for data collection was a four point-Likert type questionnaire called Nature of Educational Planning and Sustainable Development (NEPSDQ). The instrument was administered to a sample of four hundred and ninety-nine (499) education stakeholders randomly selected. The data collected from the sample were respectively subjected to statistical analysis using one way-analysis of variance (ANOVA). To further carry out the investigation three (3) hypotheses were formulated to guide the study. The major result obtained indicated that forecasting/projection, data and target setting are very essential input in planning education successfully. These variables therefore have a significant influence in planning education for sustainable development of the school system.

\section{Introduction}


Educational planning involves a scientific process and orderly thinking. In other words, it is a process of applying scientific and rational procedure to the process of educational growth and development so as to ensure efficiency and effectiveness of the educational system. According to Coombs (1970) in Nte (2005) the nature of educational planning is the application of rational systematic analysis to the process of educational development with the aim of making education more effective and efficient in responding to the needs and goals of students and society.

In many less developed countries of the world today educational planning is a recent concept. This is so because the recent interest in planning education in these developing countries arose from the recognition of the importance of education in the social and economic development of the society.

In order to utilize the scientific process in achieving a better output in planning and sustainability of the system, Nosiri in Nte (2005) suggested that the planning of education must go through the following steps; it is necessary to first recognize and define the problem involved in the planning process by identifying when to get started, who should be involved or be represented in the planning programme, hold public meetings where major educational policies and objectives are broken into requirements. In addition, identifying what needs to be done in respect of the general plan, consider the problems in several dimensions by forecasting the possible forces and alternatives (Okeke, 2006).

In addition, Kneze \& Richy (1975) in Nte (2007) observed that in planning education there is need to appraise the political, economic and social environments that will face the schools at some future point in time. In view of this Ejiogu (1999) is of the opinion that school organizational planning should involve a clear identification and definition of the desired end results of school operations. Also that planners should design and interpret what cash department, divisions and units or segment of the educational system should be doing (when, where and how) in such a way that these various activities would be properly coordinated and integrated within the system. Provision should be made in that plan so that all the personnel (staff) in the school are aware of the school policies for their own guidance in their daily operations and be prepared to handle emergencies as planning involve meaningful anticipation of critical problems.

In the planning process, this has become pertinent in that projecting or developing a scenario of the desired goal to be pursued and the administrative roles to be played in the type of future school environment envisaged, often determine change in learners which may be evident in the projected new environment.

From the foregoing, it means that, in the application of the plan for sustainable development of the school system, there is need for planners to redefine the plan through examining and matching the plan against existing policy of the education, particularly in the areas of the capital operating budget and budget for performance in the aspect of expenditure.

Inspite of this observation, Okeke (2006) research study on problems of applying planning to education revealed that the effort of planners is often fraught with some basic public and fundamental problems which border essentially on the nature of education. He stated further that the objectives of education service are exceptionally difficult to establish within the profit oriented democracy in vogue whose values in all intent and purposes are uncertain. Accordingly, there exists a basic tension between the requirements of planning and freedom. This conflicting principles between planning and freedom constitute problem in itself, the researcher is in support of the above contention and added that to achieve planning, basic education must be re-orientated to address sustainability of the school system and expanded to include critical thinking skills, skills to organize and interpret necessary data and information, skills to formulate reliable policies and the ability to analyze issues that confront education consumers. This situation is deemed highly essential for a realistic and successful education plan in the society today.

\section{Statement of the problem}

A major function of planning education is to achieve rapid social development at a minimum cost. A situation where planning education using whatever process, methods and technologies has failed to achieve positive results call for a critical re-examination of current planning practices in the south-south of Nigeria. The 
besetting problem with planning education in the south-south of Nigeria seems to be the fact that education planners and school administrators involved in the planning process are nonchalant about effective use of data, experts, professionals and work as a team towards result oriented plan for sustainable development of the education system.

The inability of planners to accurately forecast and identify the priority needs of education consumers left much to be desired. Sometimes, institutional leaders politicize the issue of planning and go through a timeconsuming and often an expensive and disruptive process in developing a reliable educational plan only to see it abandoned and ignored as anything that is truly useful. This deficient situation has contributed to the failure of most educational plans and inability to sustain development of the school system. Very often strategies to achieve the set targets of the plan are hardly met with success such that projects and programmes envisaged are not implemented/executed within stipulated time frame.

From the foregoing, it is obvious that in the face of all these problems, the two to three years education plan cannot provide reasonable solution to the education sector and above all sustainable development of the nation's economy. It appears that there is something culpably wrong with planning education in the south-south of Nigeria. These problems require very urgent remediation.

\section{Purpose of the study}

The purpose of this study is to examine the nature of educational planning for sustainable development of the school system in south-south Nigeria. Specifically the study is aimed at examining:

1. The use of forecasting in educational planning for sustainable development in the school system.

2. The usefulness of data in planning education for sustainable development of the school system.

3. The usefulness of target setting in planning education for sustainable development of the school system.

4. The use of expert/professionals in planning education for sustainable development of the school system.

\section{Research questions}

The following research questions guided the study.

1. To what extent is forecasting useful is education planning for sustainable development?

2. How is data useful in education planning for sustainable development?

3. To what extent is target setting important in planning education for sustainable development?

4. To what extent is the use of experts/professional important is educational planning for sustainable development?

Research hypothesesThe following hypotheses were formulated to guide the study. 1 . There is no significant influence of forecasting in educational planning for sustainable development. 2. There is no significant influence of target setting in educational planning for sustainable development. 3. There is no significant influence of using data in educational planning for sustainable development.

Research methodology

This study adopted survey descriptive ex-post facto design. The design was adopted because the variables under study had already occurred before the researcher conducted the study. The population of this study consisted of all education stakeholders in selected states of south-south of Nigeria. Data was collected from the state and federal educational institutions in the selected states in the study area.

The study sample was made up of four hundred and ninety-nine (499) education stakeholders randomly selected from a population of five thousand $(5,000)$ stakeholders of education. These states and institutions are Cross River State, Akwa Ibom State, River State, Bayelsa State, Edo State and Abia State respectively.

The instrument used for the study was the Nature of Educational Planning for Sustainable Development of School System (NEPSDSSQ) which was made up of fifty 50 items structured to present the respondents with a fixed set of choices. Four (4) point likert scale was used to rate the perception of the respondents on the issue of planning education; Strongly Agree (SA), Agree (A), Disagree (DA), Strongly Disagree (SD). 
The instrument was validated through submission of copies of the instrument to two experts in measurement and evaluation to confirm their face validity. . Ambiguous and irrelevant items were dropped and the instrument was reviewed and improved upon. The reliability of the instrument was determined through test-retest method using 100 respondents. The subjects used in the trial testing did not constitute part of the main sample of the study although they had similar characteristics as the respondents. This was to avoid bias.

Results

\section{Results}

\section{Hypothesis one}

There is no significant influence of forecasting in educational planning for sustainable development.

Table one

Analysis of variance (ANOVA) showing influence of forecasting in educational planning.

\begin{tabular}{llllllll}
\hline Variables & $\mathrm{N}$ & $\mathrm{X}$ & $\mathrm{SD}$ & $\mathrm{T}$-cal & Df & T-table & Decision \\
\hline Forecasting in educational planning & 313 & 24.71 & 4.42 & 2.599 & 497 & 1.645 & \\
Sustainable development & 186 & 25.69 & 3.59 & & & & \\
\hline
\end{tabular}

T-value is significant at 0.05 level

Table one above shows that there is a significant influence of forecasting in education planning for sustainable development. The T-calculated value of $\mathbf{2 . 5 9 9}$ was by far greater than the t-tabulated value of $\mathbf{1 . 6 4 5}$. This implies that forecasting in planning education is significant. This is so because the major function of educational planning is to make projection and prepare estimate on future needs, he cannot effectively do this without adequate knowledge and skills in relevant statistical tools and analysis. To draw estimate of future financial requirement and budgeting; a planner must be proficient in statistics, especially for projection or forecasting.

Hypothesis two

There is no significant influence of target setting in educational planning for sustainable development.

Table two

Analysis of variance (ANOVA) showing influence of target setting in planning

\begin{tabular}{llllllll}
\hline Variables & $\mathrm{N}$ & $\mathrm{X}$ & $\mathrm{SD}$ & $\mathrm{T}-\mathrm{cal}$ & $\mathrm{Df}$ & T-table & Decision \\
\hline Target setting in educational planning & 313 & 22.34 & 4.93 & 3.729 & 497 & 1.645 & Significant \\
Sustainable development & 186 & 24.06 & 5.09 & & & & \\
\hline
\end{tabular}

T-value is significant at 0.05 level

In table 2 the analysis shows a significant influence of setting target while planning education T-calculated value of 3.729 is by far greater than the t- tabulated value of 1.645. Thus indicated that the influence of target setting in planning education for sustainable development is significant. The result on the table therefore revealed that respondents agreed that to set target when planning education system required analysis of data to accomplish the objectives of planning education. Data analysis encourages target setting the type of target that is set depend on availability of resources.

\section{Hypothesis three}


There is no significant influence of using data in planning education for sustainable development.

Table three

ANOVA showing influence of using data in planning education system.

\begin{tabular}{llllllll}
\hline Variables & $\mathrm{N}$ & $\mathrm{X}$ & $\mathrm{SD}$ & $\mathrm{T}$-cal & Df & T-table & Decision \\
\hline Using data in planning education & 296 & 23.99 & 5.24 & 5.21 & 497 & 1.645 & Significant \\
Sustainable development & 203 & 21.53 & 4.38 & & & & \\
\hline
\end{tabular}

T-value is significant at 0.05 level

Results from table 3 revealed that there is significant influence of using data in planning education system. This is so because the t-calculated value of 5.21 is far greater than the t-table valued of 1.645 on sustainable development essentially for education to be sustained and develop planners of the education system require quantitative and qualitative data.

\section{Discussion of findings}

The nature of educational planning process for sustainable development is that type that brings about desirable changes in the curriculum and educational practices. In hypothesis one, the result is significant in the sense that for-casting or projection of future needs in planning education is very imperative for sustainable development of education system.

In support of above contention Omobola and Johnson (2010) in Atimno Babalola, Moronkola \& Atonda (2010) observed that in today's knowledge based society and global economy, education that is planned well lays the ground work for poverty alleviation and sustain economic growth. They went further to add that if sustainability is to be achieved in planning education, educators who are planners should take a leadership role, breaking new grounds to prepare the society for a change in a world of increasingly diverse and growing populations, an expanding economy and changing global environment.

In line with the findings of this study, UNESCO, (2006) in Atinmo et al (2010) advocated that to implement education planning for sustainable development, there is need to improve basic education, re-orientation of existing education programmes at all levels to address sustainable development, develop public awareness, understanding of sustainability and provide training.

The result of the analysis in hypothesis two indicated that target setting influence education planning, $t$ calculated value of 3.729 is by far greater than the t-table value of 1.645. this further revealed that influence of target setting in planning education was significant. This finding corroborate the research work of Ogunsola (2013) in Ojedele, Arikewuyo and Njoku (ed) (2013) where they affirmed that to set a target, one needs certain goal or objectives or target to accomplish. The planner(s) need to plan to guide the achievement of such goal, for any target to be achieved data analysis concerning resources availability, allocation and utilization must be continually done.

Furthermore, the result of hypothesis three indicated a significant positive influence of data on effective educational planning for sustainable development. These data covers the schools, students, teachers and non-teaching staff, population, finance, facilities and equipment, school inspection, assets and liabilities of schools and standards.

Inspite of the importance of data in planning, Ogunsola (2013) in Ojedele; Arikewuyo and Njoku (2013) observed that planning Nigerian education system has some short-coming. A major short-coming in the inadequate database available to our educational decision-makers. There are mirage of challenges in obtaining adequate and reliable data for statistical and quantitative analysis in planning education in Nigeria. Essentially however, data and information on the education system are required to make educational policies and plans. Data and statistical analysis enable assessment and evaluation of resource implications of 
educational developmental needs of the counting. The place of data and statistical analysis therefore cannot be compromised today when planning approach is now shifting from static planning to dynamic planning (Adeyemi, 2010) generally, educational related data are needed for adequate and result oriented educational planning and implementation.

\section{Conclusion}

From the analysis of the study the researcher concluded that the dynamic nature of education and its environment has indeed made it imperative that planning education should be result oriented for any school system and for the purpose of sustainable development of the society. The study also revealed that there is influence of forecasting, data and target setting on the nature of panning education in the south-south of Nigeria. Education planners should see these variables as major inputs that should be handled with severity and dexterity so as to ensure successful implementation of plans in education institutions.

Recommendations

1. There is need for planners of our education system to always involved experts/professionals in the planning process so as to ensure quality in plan preparation towards meeting the needs of the society.

2. The government should endeavour to assure the public of her interest in conducting a reliable and acceptable census for the purposes of planning.

3. Education planners need to be taught to know the value of using reliable data and information for planning purposes as data analysis will reveal the developmental needs of the states.

4. Planners of the education system should not depend on foreign planning models in African environment; these have hardly solved the educational problems.

\section{References}

Adeyemi, J. K. (2010). Statistical Analysis and Quantification in Educational Planning . Lagos: National Open University of Nigeria.

Atinmo, M. I., Babalola, J. B; Moronkola, O. A. Atanda, D. I. (2010).Education for Sustainable Development. Ibadan: University of Ibadan Press.

Egiogu, A. (1990). Educational Management. A Systems Approach; Lagos: Lantern Books Publishers.

Nte, A. R. (2005). Introduction to Educational Planning . Port-Harcourt: Mission Publishers.

Nte, A. R. (2007). Education Planning Strategies in West African Sub-Region, Port-Harcourt: Mission Publishers.

Ojedele, P. K., Arikewuyo, M. O. Njoku, A. C. (2013). Challenges of Educational Development in Nigeria, Ondo: NIEPA Publication.

Okeke, B. S. (2006). Educational Planning in Nigeria a social process approach, Akwa: Doone Printing Press. 